\title{
CHURCH AND TEMPLE IN THE NEW TESTAMENT ${ }^{1}$
}

\section{Howard Marshall}

At the time when the early church came into existence, there were three different contexts in which the Jews engaged in what we may call religious activities. ${ }^{2}$ The first of these was the temple. Although Jews lived in many places, some of them hundreds of miles from their homeland, most of them recognized only one temple, in strict fulfilment of the divine command in Deuteronomy 12; it was in Jerusalem and it was staffed by priests and Levites from the tribe of Levi. ${ }^{3}$ The temple was a large outdoor enclosure divided up into concentric courts; within the central area to which only the priests were admitted was the main altar on which sacrifices were offered, and the actual offerings were carried out by the priests, although the ordinary people were present as onlookers and could engage in prayer during the ritual (Lk. 1:10). The purpose of the sacrifices was varied; some of them were what we might call public ones, offered on behalf of the people as a whole, but the vast majority were private ones, offered by individuals for various personal reasons. ${ }^{4}$

The second context of religious activity was the synagogue. Meetings were held principally on the Sabbath, and they were characterised by the offering of prayers to God,

\footnotetext{
${ }^{1}$ The Manson Memorial lecture delivered in the University of Manchester on 2nd November, 1989. An earlier version of the lecture was given as the Annual Lecture of the Bible Training Institute, Glasgow, on 20th June, 1988. Among T.W. Manson's works there are two which are particularly germane to our topic: The Church's Ministry (London 1948); Ministry and Priesthood: Christ's and Ours (London 1958).

${ }^{2}$ R.T. Beckwith, 'The Daily and Weekly Worship of the Primitive Church in relation to its Jewish Antecedents', EQ 56 (1984) 65-80.

${ }^{3}$ There were, however, other Jewish temples where sacrifices were offered during this period. See M.E. Stone, Scriptures, Sects and Visions (Oxford 1982) 77-82.

${ }^{4} \mathrm{E}$. Schürer, The History of the Jewish People in the Age of Jesus Christ II (Edinburgh 1979) 292-313, gives an excellent detailed account.
} 
the reading of the law and other passages from the sacred Scriptures, and instruction based on the readings (Lk. 4:16-21; Acts 13:14f.). ${ }^{5}$ The synagogues were becoming increasingly important, partly because of the impossibility of attending the temple regularly and frequently. When the temple was eventually destroyed in $\mathrm{AD} 70$, its loss was much less traumatic than might have been expected because it had already been to a great extent superseded by the synagogues as the places for religious gatherings.

The third context is often neglected. This was the Jewish home. The home and the family were religious centres in various ancient religions, especially where veneration of the ancestors took place or where the family believed in its own family deities who looked after it. All this of course would have been anathema to the Jews, but the home was still important religiously. It was here that one of the most important religious festivals was celebrated annually, the feast of the Passover (Mk. 14:14f.). But in addition any formal meal was accompanied by prayers of thanksgiving to God, and the arrival of the Sabbath was also the occasion of prayer. Needless to say, individuals would also pray to God in their homes, and we can cite several examples of this practice in Scripture (e.g. Dan. 6:10; Acts 10:9).

It was only to be expected that each of these three types of religious activity would influence the practices of the early Christians. The earliest Christians were Jews, and they did not cease to be Jews when they became Christians. Consequently, they kept up the religious practices of their people.

Jesus himself went up to the temple at the religious festivals (Jn. 2:13; 5:1; et al.). He attended the synagogue regularly on the sabbath as his normal custom (Lk. 4:16). He celebrated the Passover with his disciples in the setting of a home (Mk. 14:12-26), and he prayed before meals held with his disciples (Mk. 6:41; Lk. 24:30).

The same was true of the disciples both before and after his death. The Book of Acts paints a picture of the early

${ }^{5}$ Schürer, History I (1973) 447-54. 
Christians in Jerusalem going up to the temple at the hour of prayer (Acts 3:1) and on occasion taking part in its religious ritual; even Paul is involved in the ritual surrounding Jewish vows (Acts 21:26). Similarly, the early Christians go to the synagogues as a matter of course, and they pray at mealtimes (Acts 27:35; Rom. 14:6).

There was no reason why they should give up these practices, although in course of time they found that they were not welcome in the temple and synagogue. This was because they made use of the opportunities provided to make their message known. Jesus spoke in the synagogues, and he manifestly gave his 'new teaching' which aroused various feelings of surprise, admiration, and opposition. His followers had the same experience. They seized the opportunity presented in the synagogues to proclaim the gospel, but in many cases this was unacceptable and they had to cease to attend.

Jesus also taught in the temple when he was in Jerusalem. In this case he was not taking part in the official rituals, but rather using the temple as a convenient meeting place where he could speak informally to people. Other religious leaders did the same. ${ }^{6}$ There is no telling how long Jesus might have exercised this liberty, had it not aroused the opposition that led to his arrest and execution. Similarly, his followers used the informal opportunities in the temple at first, but they speedily encountered opposition and we may presume that they were prevented from continuing to do so.

But there were no obstacles to using friendly homes for Christian purposes. Jesus gave some of his teaching in home situations, both to large groups of people and also to more intimate groups of his closest followers. The early Christians did the same. They met in a house in Jerusalem (Acts 1:13; 12:12), and we hear of house-meetings in other places as the church spread (Acts 18:7; 20:7f.). This was not surprising. There was really little other possibility for them. There were of course buildings like the lecture hall of Tyrannus which could be let out or loaned to them (Acts 19:9), but for the most part the home

\footnotetext{
6Jesus, son of Ananus, prophesied against Jerusalem and the sanctuary in the temple (Jos. Bel. 6:300). Other activities in the temple precincts included the meeting of courts (Sanh. 11).
} 
was the regular place of meeting until specifically Christian meeting places were built much later than the NT period.

We can trace the influence of Jewish religion on the infant church in all these three areas. ${ }^{7}$ The home religion of the Jews clearly influenced the practices of the Christians, and this point deserves fuller attention than we can give to it at present. The main focus of the Christian meeting was the meal held in memory of the Lord's death and as a celebration of his risen presence. Thus behind the Christian practice there lies the renewal of the Passover meal initiated by Jesus. But whereas the Passover was annual, the Christian meals were held weekly and possibly more frequently. There cannot have been too hard and fast a line between the ordinary meal and the renewed Passover meal. Further, just as a Jewish father would no doubt teach his children at home, so the home was the natural centre of instruction for Christians. Likewise, the offering of prayers would be appropriate.

Although Christians were deprived of attendance at the synagogues, they continued to follow the pattern of synagogue meetings. The influence of the synagogue is generally reckoned to be fundamental on the early development of Christian meetings. The pattern of reading the Scriptures, which gradually extended to include Christian writings, and discoursing upon them to the accompaniment of prayers was basic, and it would fit in very comfortably with the traditions derived from household religion. ${ }^{8}$

But what about the temple? How far did it influence the religious practices of the Christians? Indeed, how far did it influence their thinking? Our main concern in this paper is to explore the concept of the temple in the early church, both in its thought and in its religious practice.

\footnotetext{
${ }^{7}$ For a good, brief summary of early Christian worship in relation to Judaism see C.F.D. Moule, The Birth of the New Testament (London ${ }^{3} 1981$ ) ch. 2.

${ }^{8} \mathrm{C} . \mathrm{W}$. Dugmore, The Influence of the Synagogue upon the Divine Office (Oxford 1948).
} 


\section{II}

What exactly was the purpose and use of the temple? As we have already noted, the characteristic activity in it was the offering of sacrifice. It was the appropriate place for doing so because it was there that the deity was believed to be present, either permanently or from time to time. Pagan temples contained images of the deities who were believed to inhabit the premises. That is why the temple area was closed to all except the priests or any other people who were considered fit to approach the deity. Now Jews and Christians were well aware that God does not dwell in human shrines, as Paul reminded the Athenians (Acts 17:24). The classical OT expression of the point is in 1 Kings 8:27 where Solomon consecrates the temple and asks that Yahweh will be present there to meet his people, but he knows that Yahweh is too great for even the heavens to contain him; he transcends the temple, but nevertheless he is present there to respond to the prayers of his people. In the accounts of the tabernacle in the wilderness the divine presence is symbolised by the pillar of cloud by day and the pillar of fire by night, and it is to the tabernacle that Moses goes when we wishes to speak to God. We thus see that the nature of the activities at the temple is determined by the conviction that it is the place of God's presence, the meeting point between God and his people. This fact made the temple the centre of the life of the nation, and this is how it is presented in various ways in the OT. The vision of a new Israel in Ezekiel 40-48 places a new temple at the heart of the state.

Clearly the actual physical temple in Jerusalem was the centre of the Jewish religion so long as it stood. But alongside ideas connected with this temple we have to notice that two other kinds of idea developed.

On the one hand, already in NT times the conviction appears to have been developing that the temple was not the only place of God's presence. The Jewish sect which settled at Qumran and which was cut off from worship at the temple in Jerusalem seems to have developed the view that God was present among them when they studied the law and worshipped him. A later Rabbinic saying tells us that when two people come together to study the Torah the Shekinah rests 
upon them (P. Aboth 3.2). We have here an example of what is sometimes called spiritualisation. This phrase can be used in two ways. First, there is the sort of spiritualisation which takes place when, for example, it is recognised that the offering of a sacrifice is useless unless it is accompanied by the proper inward attitude, what one might call a sacrificial spirit. This can lead to the suggestion that the inward attitude is more important than the external offering, although at this stage the attitude and the offering are not separated from one another and both are considered essential. Secondly, the idea may develop that the internal attitude can replace the external action and render the latter superfluous. Both of these ideas can be seen in the biblical period. When the temple at Jerusalem was destroyed in AD 70 and not replaced, spiritualisation in the second sense was almost forced upon the Jews. But long before this happened a spiritualisation of the temple concept was under way. This is reflected in the NT.

On the other hand, the hope was growing that there would one day be a new temple of some kind. Sometimes the Messiah was regarded as the builder of such a new temple. At others there was the concept of a heavenly temple which would come down to earth. The earthly tabernacle was said to be a copy of a heavenly tabernacle (Ex. 25:9, 40), and heaven was sometimes pictured as being a kind of temple. This idea is developed in 1 Enoch where God dwells in a magnificent building (1 En. 14). In the Testament of Levi 3 sacrifices are offered in his presence. ${ }^{9}$

The idea of a heavenly temple is of course found in Hebrews and Revelation. In Hebrews the imagery of Exodus is taken up and used to argue from the character of the earthly tabernacle to that of the heavenly one, and this heavenly tabernacle, where Christ has offered his sacrifice, is seen to be superior to the earthly temple. In Revelation the heavenly realm is pictured in the form of a temple where worship is offered to God. When the new Jerusalem comes down to earth, however, it does not contain a specific building which is a temple; this is because God himself is present in the city as a

\footnotetext{
${ }^{9}$ For details see R. J. McKelvey, The New Temple (Oxford 1968).
} 
whole and not confined to one area of it; there is no longer any need for a temple when God is universally present.

If the New Testament thus stresses the reality of the heavenly temple, what place is there for any kind of earthly temple? And to what extent is there any reflection on earth of the heavenly temple? We must now look at the idea of the church as a spiritual temple.

In Stephen's speech we find a plain statement that God does not dwell in temples made with hands (Acts 7:48), and this is backed up from Isaiah 66:1. The question has been raised whether Stephen, having emphasised that God is not tied to the temple but has revealed himself elsewhere (including places outside the promised land), took the next step and declared that there was now a new temple. This could have been either Jesus himself ${ }^{10}$ or the church, "the corporate Christ, the Redeemer of God's elect along with His elect'. ${ }^{11}$ In many ways it would have been the logical step for him to take, and it would have provided a rationale for his arguments, but I cannot see any evidence that would prove that he had taken this step. $^{12}$ It seems more likely that Stephen was merely repeating the conviction expressed in the OT that God's dwelling place is in heaven.

However, there may be more to be said on the matter. At this point we must turn back to the Gospels. According to Mark Jesus prophesied the destruction of the temple in Jerusalem (Mk. 13:1f.). This statement or something like it was taken up and used against him at his trial: he was alleged to have said: 'I will destroy this temple made with hands and in three days build another not made with hands' (Mk. 14:58). But to what future temple was Jesus referring? A temple not made with hands means one not made by human agency. It is therefore a 'spiritual' temple of some kind. But was Jesus referring to his resurrection body, as the reference to 'three

${ }^{10}$ See A. Cole, The New Temple (London, Tyndale Press 1950).

${ }^{11}$ F.F. Bruce, Commentary on the Book of the Acts (New London Commentary, London 1954 edn.) 158

${ }^{12}$ McKelvey, New Temple 86f. It is not important for our present purpose to discuss whether these sentiments go back to the historical Stephen or were formulated by Luke. 
days' might suggest, or was he referring to the church? (Or are these the same thing, as J.A.T. Robinson argued? ${ }^{13}$ )

The problem is complicated by the account of the conversation following the cleansing of the temple in John 2:19 where Jesus is reported to have said, '[You] destroy this temple, and in three days I will raise it up'. John comments that, although his hearers thought that he was referring to Herod's temple, he was talking about the temple of his body, and that after he rose from the dead his disciples remembered the saying. That seems to say fairly clearly that he meant the temple constituted by his own body, as the place where God was present. Since the word 'body' is not used by John elsewhere for the church and there is nothing to prepare the readers for this meaning of the word, it seems unlikely that John (or Jesus) is here referring to the church. Rather Jesus himself is the true place where God's presence is revealed, both before and after his death, and the stress in the story is not on where God is now present but rather on the miracle of restoring the temple of his body.

There is the further complication that in John 2 Jesus is talking about his enemies destroying 'this temple', namely his own body, by putting him to death. But in Mark 14:58 he is alleged to have said that he himself would destroy the temple, namely the building in Jerusalem. In the context of Mark there is surely a reference back to $13: 1-4$ where Jesus prophesies that the Jerusalem temple will be destroyed, but does not actually say that he will destroy it. Further, in Mark nothing in the story prepares us for the accusation that Jesus would build a new temple.

How are we to sort out this puzzle? A possible interpretation is that Jesus prophesied both that the temple would be destroyed (Mk. 13:1f.) and that, if it was destroyed, he would replace it by another (Jn. 2:19). ${ }^{14}$ Jesus was looking forward to a new way in which God would be present on earth (cf. Mt. 12:6). In Mark 14:58 the character of this new temple is left vague, although the words 'made with hands/not made with hands' indicate that a divinely-constructed temple is in

13J.A.T. Robinson, The Body (London 1957) 51.

${ }^{14}$ On the originality and authenticity of Jn. 2:19 see McKelvey, New Temple 79. 
mind. In the trial scene these words of Jesus are taken up. The main thought is that Jesus is taking up the role of the Messiah who would build a new temple. At the same time it was easy to twist the prophecy in the light of Jesus' attack on the temple to make him say: 'I will destroy this temple', although there was no basis for this charge.

In the saying in John the form of the saying about destruction and rebuilding became: '[if you] destroy this temple, I will raise it again in three days'. The saying was obscure to the hearers. They took it to mean that if Herod's temple were destroyed, Jesus would build another miraculously, and of course they didn't believe him. However, John explains that what Jesus referred to was his own body-as the place where God was even then being revealed; if they killed him, he would raise up his body in three days, and (implicitly) he would continue to be the place of God's presence. I think that we have to see this as a deeper, secondary meaning which only became evident after the death and resurrection of Jesus.

Now if we go back to the Stephen story, we must note that the witnesses against him say that he alleged that Jesus of Nazareth would destroy the temple. They say nothing about building a new temple, and Stephen himself says nothing about this in his defence. His point is rather the general one that God's presence is not tied to buildings made with human hands. Clearly the accusations against Stephen hang together with what was said at the trial of Jesus.

The nearest we come to this idea of a new temple is in two other texts in the Gospels. In Matthew 18:20 Jesus says: 'Where two or three are gathered together in my name, there am I in the midst of them.' This is a functional statement which identifies the church as the temple and which identifies the presence of Jesus as equivalent to the presence of God. However, it does not use the vocabulary of the temple, and it remains puzzling as to where it fits into the development of ideas. The same is to be said of John 1:51 where Nathanael is told that he will see heaven open and the angels of God ascending and descending on the Son of man. There is clearly an allusion here to Jacob's dream at Bethel, and, if the place where he saw the vision and heard the divine message was none other than the house of God and the gate of heaven (Gen. 
28:17), it is surely implied that the Son of man functions similarly; Jesus is the 'house of God'. Again we have the 'temple' concept without specific temple terminology.

In view of this evidence it is hard to avoid the conclusion that in some parts of the NT Jesus himself is regarded as the temple, the locus of the presence of God among his people. C.F.D. Moule has argued that Christ is never identified with the temple, ${ }^{15}$ but the passages to which I have just referred suggest otherwise. H.W. Turner says rightly that it is Christ in union with his people who is the place where God dwells. ${ }^{16}$

\section{III}

We now turn our attention to Paul. In 2 Thessalonians 2:3f. we have his prophecy of the man of lawlessness making his way into the shrine of God and declaring that he is God. To what place is Paul referring? It seems inconceivable that he is thinking of the church, since at this time there was no church as a building for him to sit in. The imagery must refer to the temple, and the language may reflect the visit of Pompey to the temple. There is of course no throne in the temple, but this is not necessarily a stumbling block; an imposter could easily bring his own chair with him. So Paul's prophecy is of a temple which is still standing. I have argued elsewhere that this is the language of symbol and is not to be regarded as falsified by the fact that the temple in Jerusalem has been destroyed without any man of lawlessness sitting in it, nor is it to be fulfilled in a restored temple in Jerusalem, but rather it is symbolical language referring to the attempt of evil to gain universal sway in the world. It is a use of Jewish language in a Christian context akin to the usage in Rev. 11.17

The earliest documents to contain Christian thinking about the church as a new temple are Paul's letters to the Corinthians. In 1 Corinthians 3:16f. Paul says to his readers: Do you not know that you (plural!) are the shrine of God, and

${ }^{15}$ C.F.D. Moule, The Origin of Christology (Cambridge 1977) 89-94.

${ }^{16}$ H.W. Turner, From Temple to Meeting House: The Phenomenology and Theology of Places of Worship (The Hague 1979) $128 \mathrm{f}$.

17I.H. Marshall, 1 and 2 Thessalonians (Grand Rapids 1983) 190-2. 
the Spirit of God dwells in you? If anybody destroys God's shrine, God will destroy that person; for God's shrine is holy and you are it.' Here the group of Christians is regarded as a shrine inhabited by the Spirit. We should note that shortly after Paul again asks his readers: 'Do you not know that your body is a shrine of the Holy Spirit which you have from God?' (1 Cor. 6:19). Here the body of the individual believer is the shrine in which the Spirit dwells. Paul can thus make statements on the individual and the corporate planes. This suggests that he is applying imagery rather than making ontological identifications. The way in which Paul says 'don't you know?' may well imply that he thought that he was reminding his readers of teaching with which they were already familiar; it could have formed part of his earlier oral teaching to them.

What led Paul to this insight? The thought that God will dwell among his people is of course already there in the OT. Paul in fact justifies his teaching by citing from the OT in 2 Corinthians 6:16 where he quotes Leviticus 26:11f.: 'I will put my dwelling place (NIV mg.: tabernacle) among you, and I will not abhor you. I will walk among you and be your God, and you will be my people.' Paul might have referred also to Psalm 114:2: 'Judah became God's sanctuary, Israel; his dominion', or to Ezekiel 37:26f.: 'I will put my sanctuary among them for ever. My dwelling-place will be with them; I will be their God, and they will be my people.' In these passages the reference was doubtless taken to be to the tabernacle or to the temple as the place of God's presence. But Paul takes them to apply to the new Israel (i.e. the church) and to refer to the church as the place of God's presence rather than the temple. When an unbeliever comes into the meeting and hears words of prophecy, he will fall down and worship God, exclaiming, "God is really among you!"' (1 Cor. 14:25).

Here, however, we must bring in 1 Peter 2:4-10. Peter comments that believers are like living stones which are built together to form a spiritual house for a holy priesthood to offer spiritual sacrifices to God. The language indicates that the house in question is a temple. 'House of God' is a common expression for a temple. Here a number of metaphors are brought together, and believers are seen both as the stones which form the shrine and as the priests who function within 
it. It is also implied that Jesus is the foundation stone of this shrine. The mixture of images shows that the language is metaphorical and can be developed in various ways. Essentially the shrine and its personnel are identified with the group of believers: they, as it were, form the place where God is present and communicates with mankind and they render him the appropriate service.

Now the interesting thing is that much of what Peter says in this passage can be derived directly from the three OT quotations which he uses, and which are linked together by the common motif of the Stone. But what is missing in these quotations is the idea of a temple and of it being composed of believers. Or is it? The key verse is Isaiah 28:16 linked with Psalm 117:22 LXX, both of which refer to a building operation. What is being built by God? Peter appears to draw the conclusion that it is a 'house' for God himself, namely a temple. But if the building is a metaphorical one, in that Jesus is the foundation stone, is it a big jump to conclude that the building consists of his people joined and linked to him? We appear to have a creative exegesis of these verses in which the building is identified as a temple and then interpreted as a metaphorical temple consisting of people. None of this development appears to be present in Mark 12:10f. and parallels. Nor can I find it in Romans 9:33 or Acts 4:11. It looks like a separate development of thought.

But the same thought is found in Ephesians 2:19-22. Here the metaphor is developed in terms of believers being incorporated into a building on an apostolic foundation with Christ as the cornerstone. The whole building develops in to a holy shrine in the Lord, and believers are built into it to be a dwelling of God in the Spirit. ${ }^{18}$ Here we have the thought fully presented in a way parallel to that in 1 Peter but with characteristic Pauline nuances. Now the interesting point is that the line of thought that leads to this development is not any clearer in Ephesians than it is in 1 Peter 2. Why is the thought of the shrine introduced here? In Ephesians 2 the OT material is not presented explicitly (only the tell-tale

${ }^{18}$ These elements are not found in the parallel passages in Colossians. 
'cornerstone' remains). This suggests that the line of thought here is presented in a more explicit and perhaps earlier form in 1 Peter where we can see the working slightly more clearly as it were. Paul's reference to the shrine and the dwelling of God is less integral to the argument, although it brings to a conclusion the thinking earlier in the chapter where Gentiles were excluded by a 'middle wall' like the one in the temple. They are now both fellow-citizens of God's people and fellowmembers of his new shrine.

We have unearthed an intriguing development of a line of thought here. In the case of Peter it seems to go back to a creative use of two OT texts which imply that God is building a house which Peter identifies as a shrine. There is in Peter no development of a contrast with the old shrine, the physical temple in Jerusalem, and there is not much of a hint of it in Paul. That is, it looks as if the idea of a 'new temple' placed in contrast with the old is not present here. This would fit in with the fact that Stephen did not pursue that line.

\section{IV}

We have discovered a line of thought common to Paul and Peter. Was it influenced or encouraged by any ideas in the contemporary world? In a stimulating monograph published in 1965 B. Gärtner claimed to find close parallels to the NT teaching in the Qumran texts:

When these things come to pass in Israel, the Council of the Community shall be established in truth as an everlasting planting. It is the house of holiness for Israel and the Company of infinite holiness for Aaron; they are the witnesses of truth unto Judgment and the chosen of Loving-kindness appointed to offer expiation for the earth and to bring down punishment upon the wicked. It is the tried wall, the precious corner-stone; its foundations shall not tremble nor flee from their place. It is the Dwelling of infinite holiness for Aaron in <eternal> Knowledge unto the Covenant of justice and to make offerings of sweet savour; (it is) the House of perfection and truth in Israel to establish the Covenant according to the everlasting precepts. And they shall be accepted as expiation for the earth and to decree the judgment of wickedness with no perversity remaining. (1QS 8:5-10) 
This is the House which [will be built at the e]nd of days; as it is written in the Book of [Moses, In the sanctuary, O Adonai,] which Thy hands have established, Yahilwleh will reign for ever and ever... Yah[w]eh [will reign (there) for] ever; He will appear above it constantly, and strangers will lay it waste no more as they formerly laid waste the sanctualry of I]srael because of their sin. And He has commanded a sanctuary (made by the hands of) man to be built for Himself, that there may be some in his sanctuary to send up the smoke of sacrifice in His honour before Him among those who observe the Law. $(4 \mathrm{QFl} 1: 2-7)^{19}$.

These passages appear to offer close parallels to the NT teaching. They envisage the community as a building, specifically as a house, and it is associated with the offering of sacrifices to atone for sin and to honour God. Gärtner himself draws out the ways in which the NT passages are illuminated by Qumran, and it could well be that ideas of this kind were in the air and led to the development of Peter's thinking. ${ }^{20}$

Intriguing as this hypothesis is, it is not absolutely certain. An important thesis by W. Grasham has questioned the use made of these Qumran texts. ${ }^{21}$ Grasham shows that the texts are capable of other interpretations. The second text (4QFl) refers to a future temple, not to the sect itself. What the sect seems to have hoped for was the coming of a new temple, and one of their documents (the Temple Scroll) lays down rules for the organization of the temple, rather like the vision of the temple in Ezekiel $40-47$ which is an idealistic picture of the true temple. But a literal future temple is not the same thing as a spiritual present temple.

Grasham further denies that the Qumran community thought of itself as a spiritual temple with its members composing a spiritual priesthood, and he shows that the expressions which have been held to indicate this should be interpreted in a more general manner. It is true, of course, that

\footnotetext{
${ }^{19}$ Translations From A. Dupont-Sommer, The Essene Writings from Qumran (trans. G. Vermes; Oxford 1961).

${ }^{20} \mathrm{~B}$. Gärtner, The Temple and the Community in Qumran and the New Testament (Cambridge 1965).

${ }^{21}$ W.W. Grasham, The Priestly Synagogue: A Re-examination of the Cult at Qumran (unpublished Ph.D thesis, Aberdeen 1985).
} 
the sect spoke of making atonement and offering sacrifices. This strongly suggests priestly activity. Grasham has to admit that it is true that the covenanters saw their community as an atoning institution set over against the Jerusalem temple,' but he goes on to say: 'this does not mean that they, of necessity, saw themselves as a spiritual temple. ${ }^{22}$ He points out that in their eyes study and observance of the law was equivalent to sacrifice. He suggests that the sect thought of itself rather as a priestly synagogue, that is, a synagogue which was led by a group of priests rather than of lay people; if so, the Qumran sect was more akin to the synagogue organisation which was springing up in Judaism at this time.

We thus have a problem with the interpretation of these texts, as to whether they indicate that the sect saw itself as a spiritual temple or as a synagogue in which the study of the law was as effective as sacrifices. In either case, however, it seems difficult to avoid the impression that the language used at Qumran shows remarkable parallels to that used especially in 1 Peter 2 and by Paul in 2 Corinthians 6 . The view that the early church's self-understanding owed something to similar thinking at Qumran is thus fairly strongly based. We may say that in the providence of God the way was being prepared for the church to see that a literal temple and sacrifices were no longer necessary. Consequently, we may see how with the idea of the community as a temple already in the air, so to speak, it was not difficult for the early church to develop similar teaching and to use fresh OT material in doing so.

\section{V}

We have now gathered up the NT material which gives us the basis for seeing the church as having the characteristics of a temple. What effect does this theological understanding have on church meetings?

1. God can be regarded as present with his people in three ways. First, there is the fact of his omnipresence in the world. Second, he dwells with his people as individuals. And, third,

${ }^{22}$ Grasham, Priestly Synagogue 454f. 
the Christian ekklesia is the place where God meets with his people as people. No tension is felt between his omnipresence and his special presence with his people. His presence with his people represents in microcosm what is true of creation as a whole. Nor is there any tension between his presence with his people as individuals and his presence with them as community. Both individuals and community can be described as the temple of God.

2. The presence of God with his people is expressed in terms of each of the members of the Godhead. In 2 Corinthians 6:16-18, it is God the Father who dwells with his people.

But we must also remember the promise of Jesus. It is he who is present in the company of believers (Mt. 18:20). This means that Jesus is functionally equivalent to God himself. · Just as the Shekinah was present when Jews read the Torah together, so Jesus is present when his people meet in his name. Jesus himself is the 'temple' for his people (Jn. 2:21). It can be said, therefore, both that Jesus is the place where God is present and that his presence with his people constitutes them as the place of God's presence. Jesus both is the new temple in himself and constitutes his people as the new temple. While, therefore, R.J. McKelvey is right in insisting that the temple is the temple of God and not of Christ, nevertheless, he perhaps goes too far in insisting that the image is theocentric and does not have to do with the church's relation to Christ. ${ }^{23}$

Similarly, the Holy Spirit can be said to be present in the congregation and to constitute it as the temple of God (1 Cor. 3:16), just as he is with individual believers and constitutes their bodies as temples (1 Cor. 6:19). In all of these ways the presence of God is with his people.

3. It should be carefully observed that, when God's people are said to be a temple, this remark is made to different, separate groups of believers, the churches in Corinth and in Asia Minor, and by extension the churches anywhere. Evidently the imagery can be applied to any group of believers rather than to some one church. There is nothing in Christianity corrresponding to the one temple in one geographical location in

${ }^{23}$ McKelvey, New Temple $180 f$. 
Jerusalem. 'A time is coming when you will worship the Father neither on this mountain nor in Jerusalem' (Jn. 4:21). God is present wherever his people gather.

4. It follows also that the church is not dependent upon buildings, consecrated or otherwise, and that the development of the building as a sanctuary, as holy space, is alien to the trend in the NT which has spiritualised the temple. Early Christians, unlike some Jewish groups, saw no need to build a physical temple for themselves. The church as meeting house must take over from the church as holy space. ${ }^{24}$ Further, whenever Christians meet together for whatever purpose, they constitute the temple where God is present. They do not need to meet specially in order to be able to worship God, and the NT never says that they did. All their activities took place in the context of God being present with them. ${ }^{25}$

5. God is experienced as Saviour and, we must add, as Judge, by his people when they meet together.

The force of this point will become clearer if we confront it with its converse. On the one hand, his people can be assured of his presence. They don't have to do anything to bring him near. On the other hand, when his people meet together, they cannot, as it were, meet without him. They cannot hide from him. A Christian meeting cannot separate itself from the disturbing and challenging presence of God. By its very coming together it constitutes the place where God is present.

6. The meeting of God's people is thus a holy meeting. Normally the presence of God excludes everybody except the priests or other holy people from his shrine. But this condition does not exist in the NT. Already in Judaism there was no need of a special priesthood in the household or in the synagogue. Rather, access is denied to none except the impenitent believer who is under discipline. And it is important that the community is not defiled by such people. It is the impenitent, sinful believer who is excluded, not the outsider who is still seeking for salvation. The people of God are called to holiness.

\footnotetext{
${ }^{24}$ See Turner, From Temple to Meeting House.

25 I.H. Marshall, 'How far did the early Christians worship God?', Churchman 99 (1985) 216-29.
} 
7. The meeting is the place where God and his people have communion with one another. They can converse together as Moses did with God at the tent of meeting. This corresponds with the temple situation in Judaism where the priests conveyed the Torah or instruction of God to the people and where people could come and offer their prayers in the context of the sacrificial system. In the meeting believers draw near to God. There is manifestly a two-way conversation. God speaks, and his people respond to him in their prayers. Both of these aspects are important. We remind ourselves that prophets often functioned in the temple, and there were prophets associated with the temple as well as 'outsiders' who brought challenging words to the worshippers when the official functionaries had become decadent and deaf to God's voice. In addition the priests had an important role in conveying Torah to the people. Unfortunately, we think of the temple too often in terms of what we bring to God; the primary thing remains his presence with us and his word to us. Once we have heard his voice, we can respond to him with our prayers.

8. The biblical phrase for our response is offering spiritual sacrifices. This is true of the individual (Rom. 12:1) and of the church. These are not atoning sacrifices but sacrifices of praise and doing good.

The early Christians came to realise quite clearly that the death of Jesus alone was a sacrifice for sin. It was eventually seen as the one real sacrifice, to which the temple sacrifices of animals were pointers and of which they were merely shadows. It followed that for Christians there could be no question of offering any other sacrifice for sin. This line of thinking is expressed most clearly and with utter finality in the Epistle to the Hebrews. But what Hebrews says is simply the clearest expression of what is pretty well taken for granted in earlier writings in the NT. As early as 1 Corinthians Paul can say that 'Christ our passover has been sacrificed for us' (5:7). We do not know for sure how much earlier this realisation had dawned upon Christians and how far they had fully grasped its implications. Certainly we find it here within 20 years of the death of Jesus. 
In the Christian meeting the offering of sacrifice in the sense of atonement is completely ruled out because the death of Christ on the cross is seen as the complete and final sacrifice. There is no need to repeat or re-present it. Instead his people are to offer 'through Jesus... a sacrifice of praise-the fruit of lips that confess his name' (Heb. 13:15), to offer 'spiritual sacrifices acceptable to God through Jesus Christ' and to 'declare the praises of him who called [them] out of darkness into his wonderful light' (1 Pet. 2:5, 9). These two passages strongly suggest that praise is the form that sacrifice takes. We are also told that 'to do good and to share with others' is the kind of sacrifice with which God is pleased (Heb. 13:16). But it is to be offered through Jesus and is not a form of atonement.

Nothing in the NT suggests that the Lord's Supper is to be seen in any way as an offering by us to God, and the practice of offering the elements to God reverses the whole direction of the atonement in which God himself offers his Son to die and gives to us the benefits of his passion.

There is of course the OT insistence that sacrifices must be without blemish, chosen from the best animals in the flock. A modern parallel to this is often sought in the performance of elaborate music and complicated ritual by people wearing special clothes, making the church meeting extremely formal and orderly. I am very dubious how far this is the right equivalent to the OT ideal. It seems to me that it can take away from the elements of warm fellowship and of spontaneity which were also highly characteristic of early Christian meetings. We give God our best, but we remember that the NT places a low value on eloquence with words.

9. No special group of priests is required to-offer these sacrifices. The duties of the temple were exclusively performed by the priests and the levites. Again, at Qumran the priesthood formed the leadership of the community, and indeed a community without a priesthood was unthinkable. But it would have been equally unthinkable for Christians to take over priestly duties in the literal sense.

And yet, just as Christians came to think of themselves as forming a temple, so too they came to think of themselves as 
priests. We might say that just as the early Christians expanded the people of Israel to include believing Gentiles, so too they expanded the tribe of Levi to include all believers. The whole group of Christians form a spiritual priesthood according to 1 Peter, and no special priesthood is required in addition. All the believers collectively form a priesthood in the church, and I cannot see that any special priestly quality or function attaches to some Christians rather than to all. The doctrine and practice of ministry are to be developed in terms of the gifts of the Spirit, not in terms of priesthood.

10. Finally, the church as the temple of God stands under his special protection. He will destroy anybody who tries to destroy his church (1 Cor. 3:17). The gates of hell will not prevail against it (Mt. 18:18). Thus the continuing life of the church is guaranteed. There is no possibility that it will cease to exist.

\section{VI}

All this suggests that the actual ritual of the temple had little or no influence on the practices of the early Christians. If temple imagery came into the church via Qumran rather than via Jerusalem, this would further strengthen our conclusion, for then the influence would have been an indirect one. What we have established is that the characteristics of the temple were seen to be true of the congregation of God's people. God is present among them, making them his holy people. When they meet together, he speaks to them, and they respond with praise and good deeds. But there is no sense in which the specific ritual of the temple is taken over and Christian equivalents found for it. Just as the Jews came to have a spiritualised worship in the synagogue, so too the Christians did in their ekklesia. It is, then, the theology of the temple, not its practice, which is significant for the early church. The concept of the temple is part of the theology of the church, a vital part but not the only part and possibly not the most central part. In the last analysis the thought of the church as the temple serves to underline the fact that the church is the people of God, joined to him and to one another in fellowship. 